\title{
Window-Dressing Objectives of Nepalese Non-Government Organizations: Reasons and Implications
}

\author{
Keshav Prasad Shrestha ${ }^{1}$ \\ ${ }^{1}$ PhD Scholar, Mewar University, Rajsthan, India \\ ${ }^{1}$ Care Nepal, Country Office, Finance Department \\ Keshav@np.care.org,mekeshav@gmail.com
}

\begin{abstract}
Non-government organizations in Nepal upped their profile significantly during the deepening armed sociopolitical conflict in Nepal from 1996 to 2006. New non-government organizations came into being at an increasable speed and the established ones expanded their working profile. As stipulated in Nepalese law, the $N G O s$ are supposed to be purely social organization with not-for-profit motive. This study, however, finds out most of the non-government organizations in Nepal are working to meet vested interest, mainly to satisfy livelihood needs of the non-government organization operators. The window-dressing objectives of Nepalese non-government organization workers have manifold forms ranging from seeking employment to satisfying political interests. The Nepalese government is suggested to tighten up the manipulative operations of nongovernment organizations by implementing rigid monitoring of non-government organizations operations or open up a policy gateway to register non-government organizations with "earn, survive and serve" objectives.
\end{abstract}

\section{KEYWORDS}

Conflict, livelihood, Nepalese Non-government Organization (NGO), motivation.

\section{INTRODUCTION}

Non-government organizations popularly known as NGOs are ever increasing in Nepal. Nonetheless, during the People's War, they did not down size their activities even when the security situation was deteriorating. Through different means and motives they continued their operations. Obliviously, they make a significant impact as a vehicle of development in Nepal; however, they have been severely criticized for their non-transparent activities. In Nepal, formal objectives of the NGOs are subject to declaration through their constitution that is a mandatory provision for their registration. The law of the land allows NGO registration if the NGOs declare only if they declare as would be non-profit organization and commit to social betterment. Such legal provisions forced them to be officially a social organization but they are severely being alleged as deviating from their formal objectives. NGOs in Nepal are blamed on many grounds like political biasedness, working for profit, dollar-farming business motives etc. This article digs out and discusses some confessed facts by the Nepalese NGOs themselves during the study.

There are buzzing grievances related to NGOs operations in Nepal. Their work is said to suffer from a lack of effectiveness, expertise and technical knowhow; they are also alleged to operate with rudimentary accounting practices and proneness to political maneuvering and mismanagement of funds by elites and party cadres (Acharya).

Even the international donor communities have been regularly making negative comments regarding the NGO activities in Nepal. Replicated into report, it is stated that EC mission was advised that there were thousands of NGOs in Nepal and that many of them were created, often by national and local politicians, as a channel for development money. When the government changes, a new crop of NGOs is likely to spring up them. However, there are some stable older NGOs run by people with vision and commitment, organizations that dedicated to public service with a professional approach. One or two of these NGOs are based in Kathmandu and have links with organizations outside Kathmandu valley. There are several co-coordinating organizations and the mission met with the 
Federation of NGOs which appears to have a very efficient and helpful structure. There are also local NGOs at district and village levels as district development committees (DDCs) and village development committees (VDCs) have some development funds to distribute. These tend to be politicized and socially and ethnically delineated (Jon Hollants Van Loocke, 2002).

These NGOs are characterized by nepotism, donor's dependency, non-transparent and lack of professionalism. Though the Nepalese NGOs' capability and sustainability as voluntary organization have still remained questionable, they are viewed as a formidable partner in the development of Nepal (Dhakal, 2001).

Sometimes, INGOs are perceived as explained an extra layer trickling down the resources to real beneficiaries in the community. The work culture, cost effectiveness, efficiencies are tried to analyzed in the social context of Nepal where all the development actors are playing (Shrestha, 2001).

Much of what passes for civic service nowadays, through community-based organizations (CBOs), local non-governmental organizations (LNGOs) and other civil society organizations (CSOs) is thought by some to be new and novel. 'Except for a few,' writes one observer, 'all the NGOs have no roots in the native soil. They are the inventions of donor agencies' (Maskey, 1998).

NGOs are not free form criticisms as such as not being flexible, transparent and responsible as per people's expectations. Retired government officials are engaged in NGO activities, reflecting loopholes of government offices (Karki, 2004).

After the previous studies done around NGO behaviour and their motive of working in Nepalese development arena, a test through the study was made where out of 246 respondents associated with Nepalese NGOs in different capacities like Executive Members, General Members, Staff Members and Volunteers, 52.20\% expressed the reason to be associated with their NGOs are otherwise than the social service. Substantial portion of respondents opined that Nepalese NGOs were characterized by risk avoidance, influence by donors and politicians. This study sheds more light on such motives of Nepalese NGOs, based on the opinions of the respondents. This study is conducted to test the above statements and suggest ways to re-orient NGOs towards their formal objectives.

Objectives of this study are:

- Review formal vs. working objectives of Nepalese NGOs.

- Explain why the objective gaps remain

- Suggest ways to plug or at least narrow down such objective gaps.

\section{METHOD}

This study is based on the review of respondents' answers to the relevant question of NGOs' objectives. This study has taken the basis of workshop participant's responses on questionnaires. The study adopts quantitative method but banks upon descriptive method to explain the study results. As a part of the study, previous literatures have been reviewed and other documents such as NGOs Registration Act have been referred.

A workshop to achieve the study's objectives was organized. Heterogeneous NGOs representatives were invited to participate. NGOs representatives were purposefully invited to create a mixed group comprising of executive board members, general members, employers and volunteers of NGOs. 
A set of questionnaires was developed and distributed to the participants. The Nepalese NGOs getting funds from donor agencies registered into the Government of Nepal ruling body for NGOs named Social Welfare Council in FY 2067/68 were 568 which were taken as population for the study. Taking the random sampling formula at $95 \%$ level of confidence with 5\% margin of error responses altogether 246 respondents' responses were collected through the questionnaire survey.

In this study, respondents are from all over Nepal, representing five development regions of Nepal. Respondents are involved in different capacities like executive members, senior staff, junior staff, general members, volunteers etc.

Out from the numbers of questions in the questionnaire, only the relevant responses of the NGOs formation objectives part's responses have been picked up to align with this article. The responses pertinent to the NGOs operation objectives in contrast to the official objectives presented to the Government of Nepal during the NGOs registration time are picked up, tabulated and analyzed in this article.

\section{RESULT}

This study covers following regional respondents, covered nationwide. Respondents from different sectoral NGOs like national NGOs, international NGOs, and bilateral and multilateral organizations are involved. Respondents hold different capacities in the organization. Following are some tables in summary.

Table 1: Region-wise coverage of respondents

\begin{tabular}{|l|r|r|}
\hline Regions & Respondents & Percentage \\
\hline Eastern Region & 30 & $12.20 \%$ \\
\hline Central Region & 57 & $23.17 \%$ \\
\hline Western Region & 27 & $10.98 \%$ \\
\hline Mid-Western Region & 86 & $34.96 \%$ \\
\hline Far-Western Region & 46 & $18.70 \%$ \\
\hline Total & $\mathbf{2 4 6}$ & $\mathbf{1 0 0 \%}$ \\
\hline
\end{tabular}

Field Survey: 2013

Table 2: Types of organizational respondents involved in study

\begin{tabular}{|l|r|r|}
\hline Types of Organization & Number & Percentage \\
\hline National NGO & 226 & $91.87 \%$ \\
\hline International NGO & 14 & $5.69 \%$ \\
\hline BILATERAL agencies & 4 & $1.63 \%$ \\
\hline MULTILATERAL agencies & 2 & $0.81 \%$ \\
\hline TOTAL & $\mathbf{2 4 6}$ & $\mathbf{1 0 0 \%}$ \\
\hline
\end{tabular}

Field Survey: 2013

Table 3: Capacities of the respondents involved in the study

\begin{tabular}{|l|r|r|}
\hline Capacity of Respondents & Number & Percentage \\
\hline Executive Committee Members & 84 & $34.15 \%$ \\
\hline General Members & 15 & $6.10 \%$ \\
\hline Staff & 142 & $57.72 \%$ \\
\hline Volunteer & 5 & $2.03 \%$ \\
\hline
\end{tabular}


Field Survey: 2013

In response to the semi-structured question why the associated people with Nepalese NGOs are running NGOs, $47.06 \%$ participants said they worked for purely social motive. The strict legal provision of Nepal says that until and unless NGOs officially declare that are absolutely inspired not for profit. Outlook, they cannot exist more in the eye of law. However, the very low number of respondents agrees to this. This is clearly shows that Nepalese NGOs are operating in contravention of the law.

The responses received are tabulated as under follows:

Table 4: Responses on the objectives being involved in NGOs

\begin{tabular}{|l|c|}
\hline \multicolumn{2}{|c|}{ Objectives of working in NGOS } \\
\hline Responses category & Percentage \% \\
\hline For livelihood & $17.96 \%$ \\
\hline For professional career development & $22.29 \%$ \\
\hline For social service & $47.06 \%$ \\
\hline Using NGO as a platform for better career & $5.57 \%$ \\
\hline Others & $5.57 \%$ \\
\hline Unanswered & $1.55 \%$ \\
\hline
\end{tabular}

Field Survey, 2013

Contrasting views received from respondents are that are operating in a state of dilemma. By nature, they have to work on social issues for social betterment but in reality they work for their own livelihood through NGOs. Self-employment is the main driving force for them. A major portion (52.94\%) agreed that they were working for other than social service motive in clear contravention of the legal provision. They further elaborated that formation of NGOs have two fold twofold benefits serving the society as earning their own livelihoods.

They further agreed that the deviation from the social motives had become a trend in Nepal. Most elite, neo-elites groups are interested in running NGOs in Nepal. There exists an irony about NGOs that folks who fail to get employment become successful owners of NGOs. Nothing additional qualification is required except for excellent accommodating nature with donors' interest and a perfect project-begging skill. When asked whether they know or feel that there are hidden objectives of their NGOs at odds with the official objectives, $59.52 \%$ responded that such hidden objectives did not exist. What this means is that still substantial $40.48 \%$ cannot clearly say that there are no such hidden objectives. $21.43 \%$ feel that there are hidden objectives underlying in their NGOs. The table below depicts the results:

Table 5: Response on hidden objectives present in NGOs.

\begin{tabular}{|l|c|}
\hline \multicolumn{2}{|c|}{ Is there hidden objectives in your NGOs? } \\
\hline Responses category & $21.43 \%$ \\
\hline Yes & $59.52 \%$ \\
\hline No & $13.89 \%$ \\
\hline Cannot say & $3.57 \%$ \\
\hline Unanswered
\end{tabular}

Field Survey, 2013

Here come responses from respondents on question why there officially conflicting hidden objectives exist in the NGOs? Quite substantial $42.31 \%$ respondents did not answered whereas 
$13.06 \%$ mentioned it was because of the wish of NGO founders and $36.15 \%$ blamed to the "situational factors". Such situational factors may range from organizational survival to political interests or the money-making interest. The responses tabulated are:

Table 6: Reasons having hidden objectives in NGOs

\begin{tabular}{|l|c|}
\hline \multicolumn{2}{|c|}{ Why there are hidden objective exist in NGOs? } \\
\hline Responses category & Percentage \% \\
\hline Because of wish of NGO founders & $13.08 \%$ \\
\hline Because of situational reasons & $36.15 \%$ \\
\hline Because of bureaucratic system of the NGOs & $2.31 \%$ \\
\hline Others & $6.15 \%$ \\
\hline Unanswered & $42.31 \%$ \\
\hline
\end{tabular}

Field Survey, 2013

Since the unanswered category represents responses from the respondents only who said there were hidden objectives but they did not wish to say the reasons, it indicates that people are either reluctant or unable to furnish reasons of the hidden objectives of NGOs, though they agreed that hidden objectives existed there.

\section{DISCUSSION}

Referring to the previous studies mentioned above, these findings also support to the statements extracted from the studies or reports. There are similarities in findings with the information available in secondary. This all indicates there are only window-dressing of formal objectives outlined in the constitutions of the Nepalese NGOs and the grey area in operational objective appears.

Executive committee members and staff are main show runners in NGOs. Their fair representation in the survey provides basis for forming the conclusion that mainstream of Nepalese NGO runners are deviating from the official organizational objectives. This opens up a wider study that invites questions on the legitimacy of NGO operations in Nepal.

New series of questions may arise. Does this mean Nepalese NGOs operators were putting their lives into jeopardy, even when the situation was worsening during the decade-long period of armed conflict in Nepal? Looking at positively and objectively was this because of swelling love for motherland or due to something else? Who can escape from the risk when the whole boat is sinking or were there driving factors? What all these questions indicate is that the period of armed conflict that means whatever the Nepalese NGOs did during armed conflict period - no matter how much ulterior their motives were something was better than doing nothing which may further detailed study.

Let me concentrate on the article topic - whatever the situation may be behind the action, Nepalese NGO's formal objectives are fairly window-dressed. Their formal objectives just dots on a piece of paper and most of the NGOs are deviating from their objectives, though the degree of the deviation may vary from organization to organization.

The fundamental principle of establishing social, nonprofit organizations is violated in Nepal. Despite the various reasons given by the Nepalese NGOs operators, the NGO operation should either come to end or customized legislation should come in force. What could the government of Nepal cdo in this regard? The government was obsessed with peace building initiatives during the conflict and other things did not attract its attention? Poor monitoring of NGO activities compounded the crisis.

So, what next can be suggested to the government of Nepal? Despite sharp criticisms, it is obvious that people wish to work in social field if their basic livelihood requirements are fulfilled. 
NGOs registration need to pass through some rigorous assessments of the proposed NGOs. Their past history in the involvement of social organizations, their status of social reputation and involvement of socio-economic activities could be some of the major components of assessments. The avowed objectives of the proposed NGOs should be based on reality rather than idealism. All these can be done if the government tightens rules.

For a monitoring of the ongoing activities of NGOs, amendments in existing law might help. Adding resource to the monitoring government agency is also equally important. In a district, just one person is responsible for NGOs' registration. In a district - even one that is remote- has minimum 200 NGOs and the number is ever increasing. In such a situation human and other physical, financial resource injection is an absolute need for an effective monitoring.

A coin has other side as well. Rigid legislation only might not be a foolproof solution. Some scholars say that not rigid laws but flexible provisions will help more. Result-oriented friendly legal support will provide motivation to the NGOs workers, which will ultimately add value to the development initiatives.

Other major contributors are INGOs, bilateral / multilaterals agencies utilizing Nepalese NGOs strength of social mobilization and local expertise. Very less effort seems to strengthen Nepalese NGOs' capacity building part by such foreign agencies. Their major efforts seem concentrated in managing their development through NGOs. Consuming the allocated budget in their planned field is being perceived as a great success criterion for the INGOs, bilateral and multilateral agencies.

There is a very thin demarcation line between CBOs and NGOs. The line is also called one by the NGOs. CBOs have clear objectives, specifically aligned with the sectoral development activities such as drinking water, irrigation, rural roads, non-formal education, income generating activities etc. Absence of vague and broad looking objectives as those of the NGOs help them to keep themselves on track. Most of the CBOs remain management committee of specific community initiatives. However, few of them seem to have grown up to the local level of NGOs with broad and vague objectives. In the long run, they may get infected and may lean towards window-dressing of their formal objectives and develop a hidden agenda.

I respect the privacy of the respondents. Categories of respondents like executive members, general members and NGO staffs have conflicting suggestions about on the organizational objective variations. It is interesting to note that many layers exist in the Nepalese NGOs hierarchy and structure; each belong to a class and has diversified interest and opinions, sometimes even exclusive to each other. The largest group contains the general members who participate in the so-called apex body of NGOs - its general assembly. They admit that their NGO's objective is window-dressed and that it must come to an end. They are clear and loud but have little influence on decision making and thus are virtually helpless. Some of them get manipulated, many of them give up and few of them stand but ultimately they found themselves in minority. The second group has a mediocre number of people. This group has dreams to lead their organizations someday. Its response is mixed and usually camouflages the leader's weakness. The people of this group portray themselves as a future leaders and such many of them accept the institutional objectives window-dressing. Finally, no need to say, top leaders of Nepalese NGOs usually claim that there is no any window-dressing of objectives in their organization and that they run NGOs with the pure and humble social motive.

\section{CONCLUSION}


This study asserts that Nepali NGOs' sustainability as purely social organizations is a far cry and that the operators' greed and accompanying psychological factors have resulted into an underlying, latent motive that is ulterior but is window-dressed as a social motive. It is high time to look for alternative ways to extract better results from the NGOs' work. It is also time to start bigger discussion that if Nepalese NGOs cannot survive in line with their avowed social motives why not allow them to run as social business entities thereby allowing them to retain profits and ploughing back such profits into further social development initiatives?

Looking at the substantial resource mobilization by the NGOs, mushrooming of NGOs in every general or specialized sectors of development, it seems quite challenging to streamline their activities for the betterment of the society. What is the root cause and where does the solution lies? Some of the suggestions given above might throw some light over the issue but an extensive research remains a productive necessity.

\section{BIBLIOGRAPHY}

Acharya, M. (1997). Non-government organizations (NGO)-led development in Nepal. (K. B. Bhattachan, Ed.) Kathmandu, Nepal: Central department of Sociology and Anthropology (DOSA), TU.

Dhakal, D. R. (2001). Problems and prospects of relation between government organization, NGO/INGOs in Nepal. In K. B. Bhattachan, NGO, civil society and government in Nepal (pp. 105128). Kathmandu: Central Department of Sociology and Anthropology (DOSA), Tribhuwan University.

Jon Hollants Van Loocke, L. P. (2002). Report on the EC Conflict Prevention Assessment Mission. Kathmandu: European Commission.

Karki, A. (2004). NGOs in Nepal : Structures and Networks. In Sahakarya, Non-government organizations challenges and opportunities (pp. 2-3). Kathmandu: Sahakarya.

Maskey, B. K. (1998). Non-government organizations in development: search for a new vision. Kathmandu: Center for Development and Governance.

Shrestha, B. K. (2001). The sociological context of (I)NGO work in Nepal. In K. B. Bhattachan, $N G O$, civil society and government in Nepal (pp. 41-62). Kathmandu: Department of Sociology and Anthropology (DOSA), Tribhuwan University. 